\title{
DISTORTED: A VIEW OF CANADIAN MULTICULTURALISM WITHIN A BILINGUAL FRAMEWORK
}

\author{
HANSON R. HOSEIN ${ }^{*}$
}

The author explores the question of whether multiculturalism can exist within Canada's system of official bilingualism. He begins by presenting $a$ theoretical definition of multiculturalism. This is followed by an overview of its historical development in Canada and a conclusion that multiculturalism, as it actually exists today, falls short of the theoretical definition and, therefore, is a failure. In order to rectify this problem, the author calls for a reevaluation of Canada's legal system so that laws which unintentionally discriminate against certain groups can be identified and amended. He emphasizes that Canada's official languages policy must not be viewed as an official cultures policy and proposes that Canada should be regarded as being a "pioneer" society in which the concept of official founding peoples has no place.
L'auteur se demande si le multiculturalisme peut exister au sein du système canadien de bilinguisme officiel. II commence par présemter une définition théorique du multiculturalisme. donne ensuite un aperşu de l'évolution historique du phénomène au Canada, et conclut à l'échec du multiculturalisme tel qu'il existe aujourd'hui, parce qu'il ne correspond pas à la définition théorique. Pour rectifier ce problème, lauteur réclame une révaluation du système actuel, qui permettrait de reconnaître et de modifier les lois qui désavantagent involontairement certains groupes. II souligne qu'il ne faut pas voir en la politique des langues officielles du Canada une politique des cultures officielles. II soutient que le Canada devrait être considéré comme une société de «pionniers», où la notion de peuples fondateurs officiels n'a pas sa place.

\section{TABLE OF CONTENTS}

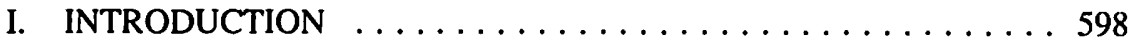

II. THE SCOPE OF MULTICULTURALISM $\ldots \ldots \ldots \ldots \ldots \ldots 59$

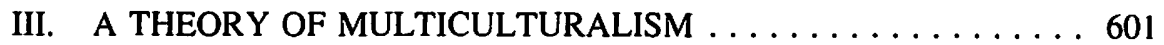

A. THE PROBLEM OF COLLECTIVE RIGHTS ........601

B. EQUALITY AND DIFFERENCES ............663

IV. THE HISTORY OF MULTICULTURALISM

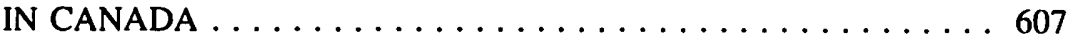

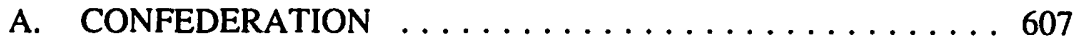

B. THE 1960s: THE ROYAL COMMISSION

ON BICULTURALISM AND BILINGUALISM . . . . . . . 607

C. THE 1970s: MULTICULTURALISM WITHIN A BILINGUAL FRAMEWORK . . . . . . . . . . . . 609

D. THE 1980s: CONSTITUTIONALIZATION

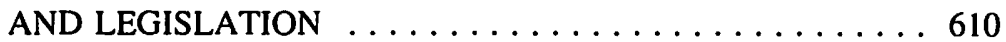

V. THE REALITY OF CANADIAN MULTICULTURALISM $\ldots \ldots 612$

A. THE AMBIGUITY OF THE OFFICIAL

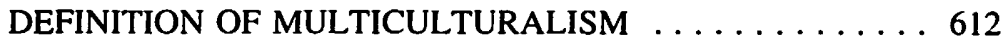

B. THE NEXUS OF LANGUAGE AND CULTURE . . . . . . 613

Third year LL.B./B.C.L. candidate, McGill University. The author would like to thank Professor Colleen Sheppard, David Chemla, Brian Cohen, Anna Kim and the author's family for their assistance and inspiration. 


\section{THE FAILURE OF MULTICULTURALISM}

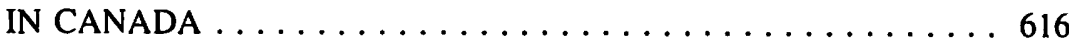

A. THE HIERARCHY OF CULTURES:

QUEBEC .....................616

B. REBUTTING THE ARGUMENT FOR

MULTICULTURALISM WITHIN A

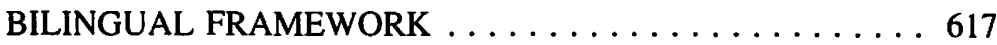

C. THE ROLE OF INTERNATIONAL LAW . . . . . . . 619

VII. CONCLUSION .......................620

A. THE PRESENT SITUATION $\ldots \ldots \ldots \ldots \ldots \ldots \ldots \ldots 620$

B. SUGGESTED APPROACHES $\ldots \ldots \ldots \ldots \ldots \ldots \ldots \ldots 621$

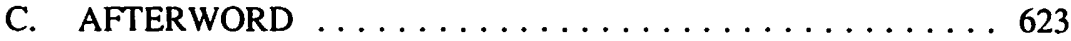

\section{INTRODUCTION}

....T There cannot be one cultural policy for Canadians of British and French origin, another for the original peoples and yet a third for all others. For although there are two official languages, there is no official culture, nor does any ethnic group take precedence over any other.... A policy of multiculturalism wirhin a bilingual framework commends itself to the government as the most suitable means of assuring the cultural freedom of Canadians.'

These words heralded the beginning of Canada's pursuit of multiculturalism as a public policy. They also established the parameters within which multiculturalism was to exercise its mandate for the next twenty years and, ultimately, assured that any attempt at multiculturalism in Canada would be stillborn, for it is this structure of multiculturalism within a bilingual framework that impedes multiculturalism from realizing its ultimate goal of equality.

The importance that equality holds in any understanding of multiculturalism is often overlooked in favour of the more commonly recognized aim of the promotion of cultural diversity. However, this promotion of diversity is merely the means. The foundation of multiculturalism is based on the concept that for all members of society to achieve a satisfactory, material condition, there must be a favourable system of opportunities.' Such a system requires not only an absence of barriers but also an institutional structure that offers possibilities for the discovery of an individual's identity. The latter is necessary so that all persons may meaningfully participate in society and attain social recognition of their culture and their differences. ${ }^{3}$ As a result, "[m]ulticulturalism is an

1. Canada, House of Commons, Debates at 8545 (8 October 1971), statement of former Prime Minister Trudeau [emphasis added].

2. R. Breton, "Multiculturalism and Canadian Nation-Building" in A. Cairns \& C. Williams, eds., The Politics of Gender. Ethmicity and Language in Canada (Toronto: University of Toronto Press, 1986) at 28.

3. Ibid.; N. Duclos, "Lessons of Difference: Feminist Theory on Cultural Diversity" (1990) 38 Buffalo L.R. 325 at 337. 
affirmation of our commitment that Canadians of all ethnic ... backgrounds have the right to equal recognition and equal opportunity in this country." All of this is reflected in the preamble of the Canadian Multiculturalism Act:

AND WHEREAS the Government of Canada recognizes the diversity of Canadians as regards race, national or ethnic origin, colour and religion as a fundamental characteristic of Canadian society and is designed to preserve and enhance the multicultural heritage of Canadians while working to achieve the equality of all Canadians in the economic, social, cultural and political life of Canada...'

The reasons why multiculturalism is unable to realize its goal of equality will be the subject of this paper. Specifically, I will attempt to answer the following key questions: (1) Why is the recognition of diversity essential to the promotion of equality among cultures? (2) What is meant by the terms "equality," "multiculturalism," "difference," and "culture" as they relate to Canadian policy over the last two decades?

Responding to these questions will require a historical overview of the Canadian experience which will show how the government's policy of biculturalism evolved into one of multiculturalism within a framework of official bilingualism. Ultimately, I conclude that maintaining this structure, whose premise originated in the 19th century, is no longer appropriate at the end of the 20th century.

\section{THE SCOPE OF MULTICULTURALISM}

A major criticism of multiculturalism is that the concept of complying with it knows no bounds. How far do we go in accommodating cultural difference? This consideration involves investigating whether supporting multiculturalism might, for example, include promoting the provision of public education in any language upon demand, or whether legislation should be translated into languages other than English and French. More difficult issues arise when we discover that multiculturalism could require the modification of seemingly "culture-neutral" institutions (i.e. institutions that do not exemplify or reflect any one culture) in order to accommodate cultural diversity. An example of this is whether Sunday, a day representative of the Christian Sabbath, should be the weekly day of rest in a country where a multitude of people see Wednesdays, Fridays and Saturdays as fulfilling this purpose.

Another complicated issue is whether the ethnocentricity of the English common law can be changed in order to cater to multiculturalism. Even in England, the legal system has come under pressure from some Muslim community groups who wish to establish a distinct system of family law founded on Islamic principles. Closer to home, we can

4. Operation of The Canadian Multiculturalism Act: Ammual Report 1988/89 (Ottawa: Minister of Supply and Services Canada, 1989) at ix, quoting Prime Minister Mulroney.

5. S.C. 1988 , c. 31 [emphasis added]. 
observe how the legal system has been inadequate in accommodating the way of life of various aboriginal peoples groups. ${ }^{6}$

Responses to these difficult issues could be limited to simple answers such as unavailability of funds and resources to provide for accommodation to such an extent. They might also be extended as far as being philosophical/political arguments in which it could be contended that culture must be sacrificed for elements of social commonality in order to promote national unity and national identity so that we have some principles which we can all identify as being inherently "Canadian."

Due to the attractiveness and potency of these objections, the argument presented in this paper may not appear to be a satisfactory resolution of these inevitable problems of the potential scope of multiculturalism. My aim is, however, to reveal that multiculturalism has failed to meet its objectives and that its resurrection as a viable policy is incompatible with the present political, legislative and constitutional structure of bilingualism.' In my conclusion, I suggest approaches of how to deal with this incompatibility. In doing so, I recognize, however, that the potential scope of multiculturalism may prove to be too great for a Canadian multiculturalism policy to fully deal with cultural difference. With these considerations in mind, I will now develop a theory of multiculturalism which shall be subsequently used to evaluate the success of the Canadian experience.

For examples of this, see P. Macklem, "First Nations Self-Government and the Borders of the Canadian Legal Imagination" (1991) 36 McGill L.J. 382; A-K/M.E. Turpel, "Aboriginal Peoples and the Canadian Charter of Rights and Freedoms: Contradictions and Challenges" (1989) 10 Canadian Women's Studies 149.

7. Note that aboriginal peoples present, for the most part, a special situation in the context of multiculturalism. On the one hand, aboriginal grievances with the European-based legal system and the failure of the govemment to adequately recognize their differences are shared by other minority groups in Canada, as is noted by Macklem, ibid. at 395. On the other hand, many aboriginal peoples' claims are more far-reaching than demands by non-native groups; as Turpel states, ibid. at 151, "aboriginal cultures are the manifestations of a different human (collective) imagination." Their objectives thus, extend to self-government - even sovereignty in some cases.

In "Aboriginal Group Rights and Environmental Protection" (1991) 36 McGill L.J. 925 at 942, R. Kapashesit and $\mathrm{M}$. Klippenstein accentuate a further possible difference between aboriginal peoples and non-native groups. This is done through the distinction that is made between minority groups who consent to a "liberal individual political structure" and aboriginal communities who have not consented to any such structure.

Nevertheless, some very poignant examples involving aboriginal peoples within the context of this argument do exist. For this reason, some of these examples will be employed. I do acknowledge. however, that ultimately a judicious treatment of these important native issues is beyond the scope of this paper. 


\section{A THEORY OF MULTICULTURALISM}

\section{A. THE PROBLEM OF COLLECTIVE RIGHTS}

As a concept, multiculturalism is said to offend the classical liberal notion of individual rights. An individual right demands that everyone be treated the same regardless of a person's membership in a particular identifiable group. Such a right usually requires noninterference of the state. ${ }^{8}$ Conversely, a group right is a claim made by an individual or a group for rights because of membership in an identifiable group. This type of right usually requires positive state action. ${ }^{9}$ Multiculturalism is part of this group interpretation.

With its preoccupation with individuals, liberalism has not traditionally embraced group rights. It has historically abhorred state interference. It is wary of the potential for conflict with individual rights when official sanction is given to membership and

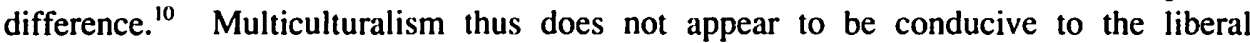
premises upon which Western society was founded. In contending with this problem, I will present two possible interpretations of how we can recognize multiculturalism in a traditionally liberal society.

\section{Interpretation \#1: Group Rights Exist Today}

First, in order to deal with multiculturalism, we must accept that our society is no longer structured wholly on the 19th century premise of individual rights. One may cite ss. 16-22, 23, 29, 35 and $37^{11}$ of the Constitution Act, $1982^{12}$ as evidence of the constitutional recognition of group rights. Meanwhile, section 27, the multiculturalism provision of the Canadian Charter of Rights and Freedoms, ${ }^{13}$ is understood as an "interpretive provision protective of groups." 14 Indeed, as one commentator put it,

W. Tarnopolsky and W. Pentney, Discrimination and the Law, rev'd ed. (Toronto: Richard de Boo, 1985) at 16-27.

9. Ihid. 16-29; a possible subset to the understanding of collective rights is "nationhood rights." This involves collectivities with links to an ancestral/territorial base who perceive that they have been subject to national discrimination. If such a right exists, it lends further credence to my statement that aboriginals should not be wholly included in this argument. See E. Kallen. "The Meech Lake Accord: Entrenching a Pecking Order of Minority Rights" in M.D. Behicls, ed., The Meech Lake Primer (Ottawa: University of Ottawa Press. 1989) 349 at 353.

For example, see the much-criticized case of A.G. Canada v. Lavell. [1974] S.C.R. 1349, where legislation clearly discriminating against women was upheld in the name of minority rights.

1. Duclos, supra, note 3 at 347 . The enumerated provisions deal with official language rights, denominational school rights, and aboriginal rights.

Being Schedule B of the Canada Act 1982 (U.K.), 1982, c.11.

Part I of the Constitution Act, 1982, being Schedule B of the Canada Act 1982 (U.K.). 1982, c.11.

Duclos, supra, note 3 at 347: along with ss. 25, 26 and 28.; section 27 reads:

This Charter shall be interpreted in a manner consistent with the preservation

and enhancement of the multicultural heritage of Canadians.

Note also that the Quebec statutory version of s. 27 is explicitly group-oriented: 
although group rights litigation in Canada is usually unsuccessful, and relatively adversarial, a combination of s. 27 and s. 1 could give group rights more power. ${ }^{15}$ This is, in fact, what was done in $R$. v. Keegstra. ${ }^{16}$ In that case, the majority of the Supreme Court of Canada used s. 27 in a s. 1 analysis to restrict the accused's freedom of expression, a classically liberal freedom, so that it could prevent the promotion of hatred against identifiable groups. In neglecting to do otherwise, according to Chief Justice Dickson (as he then was), multiculturalism could not be preserved nor enhanced. ${ }^{17}$

A stronger statement supporting the existence of group rights was made by the Supreme Court in Mahe v. Alberta. ${ }^{18}$ Here, the court described s. 23 of the Charter as "a novel form of legal right" which imposed a positive obligation on the government to alter and develop the institution of minority language education. ${ }^{19}$ Consequently, both Mahe and Keegstra ${ }^{20}$ may indicate an abandonment of traditional judicial reluctance to accept group rights. Nevertheless, there remain equally strong indications that this new approach will not be readily accepted. ${ }^{21}$

\section{Interpretation \#2: Multiculturalism within Liberal Theory}

An alternative way in which to deal with group rights is to attempt to fit them into liberal theory itself. In fact, as Will Kymlicka argues, cultural membership is an inherent aspect of individualism.22 $\mathrm{He}$ contends that according to liberalism, the freedom to form and revise beliefs about values is a critical precondition for the pursuit of a good life. ${ }^{23}$ In other words, it is crucial to one's self-respect to see the value of one's activities. Beliefs about this value come from cultural heritage, a concept that includes both language

Persons belonging to ethnic minorities have a right to maintain and develop their own cultural interests with the other members of their group (Quebec Charter of Human Rights and Freedoms, R.S.Q. 1977, c. C-12).

J.E. Magnet, "Multiculturalism and Collective Rights: Approaches to Section 27" in G.A. Beaudoin \& E. Ratushney, eds., Canadian Charter of Rights and Freedoms (Toronto: Carswell, 1989) 739 at 774. Section 1 of the Charter allows for the "reasonable" limitation on protected rights and freedoms when it is found that government legislation has infringed a right or freedom. Thus $\mathbf{s .} 27$ used in conjunction with s. 1 would justify the upholding of a law limiting a freedom such as expression if it would further the preservation and enhancement of the multicultural heritage of Canadians.

16. [1990] 3 S.C.R. 697.

17. Ibid. at 758.

18. [1990] I S.C.R. 342.

19. Ihid. at 365 .

20. Where Dickson C.J. goes on to say that ss. 16-23, 25, 28, and 29 are a reflection of the fact that an individual can be affected by treatment of a group to which he or she belongs, supra, note 16 at 757 .

21. See particularly C. Sheppard's comments in "Recognition of the Disadvantaging of Women: The Promise of Andrews v. Law' Society of British Columbia" (1989) 35 McGill L.J. 206 at 224, where she remarked that the landmark case of Andrews v. Law Society of British Columbia, infra, note 27, repeatedly refers to "individuals and groups" rather than just "groups." Such a reluctance to abandon individuals perhaps reflects conventional societal regard for human rights as individual rights.

22. W. Kymlicka, Liberalism. Community and Culture (Oxford: Clarendon Press, 1989).

23. Ibid. at 163, paraphrasing Jolin Rawls. 
and history. Thus, cultural heritage is important not only because of its moral status, but also because it allows people to become more vividly aware of the options open to them. ${ }^{24}$

As a result, the crux of Kymlicka's argument is that a more-than-equal share of government effort and resources must be given to minorities so that their cultures can be protected. The "dominant culture" after all is able to secure this for free. ${ }^{25}$ Essentially then, because of its importance to the individual, multiculturalism can be justified through the principle that cultural membership should be equally available to all. To some extent, such a view has been espoused by the Supreme Court of Canada, in Keegstra where Dickson C.J. stated:

...I expressly adopt the principle of non-discrimination and the need to prevent attacks on the individual's connection with his or her culture, and hence upon the process of self-development. ${ }^{26}$

\section{B. EQUALITY AND DIFFERENCES}

Given the above discussion of the possible classifications of multiculturalism as being part of a group right interpretation (reluctantly accepted) or an individual right (tenuous perhaps, but more acceptable in our traditionally liberal society), multiculturalism's ultimate goal of equality is still well within the liberal framework. This is achieved through the accommodation of differences which "is the essence of equality," according to Andrews v. Law Society of British Columbia. ${ }^{27}$ However, for equality to be achieved in this manner, differences must not only be accommodated, but emphasized as well. Without an emphasis on difference, there is a danger that a concept of "universal humanity" will settle in so that the practices of the dominant group in society appear universal and neutral. ${ }^{28}$ As a result, practices by other groups will be marked with par-

Ibid. at 165.

25. Ibid. at 187. This proposition suggests an affirmative action-type approach to supporting minorities. Consequently, it may be possible to promote multiculturalism without resorting to a group right interpretation. Such an approach could be justified under s. 15(2) of the Charter which states that the equality rights of s. 15(1) do not preclude any law, program or activity that are "aimed at ameliorating the conditions of those who are disadvantaged because of such personal characteristics." This characterization of s. 15(2) was made in Harrison v. University of British Columbia. [1990] 3 S.C.R. 451 at 474 , where Wilson J. goes on to say that in order to employ such a measure, it must be first established that this measure will address the effects of discrimination against a disadvantaged group. Of course this approach does not make multiculturalism a "right." Rather, this method's reliance on the government's agenda as to who should be targeted by policy or law might diminish its usefulness to this discussion.

26. Supra, note 16 at 757.

27. [1989] I S.C.R. 143; 56 D.L.R. (4th) 1 [hereinafter cited to D.L.R.] at 13.

28. I.M. Young, Justice and the Politics of Difference (Princeton: Princeton University Press, 1990) al 165. A common definition of the "dominant culture" is that it is "adult, whitc. male, heterosexual. English-speaking, thin, loosely Christian. able-bodied, university-educated, professional, propertied," in Duclos, supra, note 3 at 370. 
ticularity. If these groups do not feel pressure to adhere to the dominant norm, they will nonetheless be considered "different."

For example, a native person might be considered "disadvantaged" if she does not possess the economic status required by "the white middle-class yardstick" to be deemed "equal."29 Those people who do not value material prosperity - considered by most to be a "universal" virtue or proper measure of well-being - are keenly aware that this norm is not culturally neutral, but in fact reflects the values of the dominant group perpetuated through time. Thus failing to disclose the norm's culturo-ideological content, fosters the belief that certain dominant or mainstream values, such as materialism, are universal, and that only the minority cultures are "different" and, therefore, unequal. The dominant norm appears to be superior to the cultural values held by other groups and, therefore, as something that should be adhered to.

Sunday/religious holiday business closings legislation is a less obvious and more controversial instance of the notion of a seemingly universal and neutral practice actually reflecting the majority norm. The courts, particularly in the cases of Edwards Books and Art Ltd. v. R. ${ }^{30}$ and Peel (Regional Municipality) v. Great Atlantic \& Pacific Co. of Canada Ltd., ${ }^{31}$ have maintained the argument that the purpose of such laws, although historically based on Christianity, is now secular in nature. They hold that a common pause day is consistent with the promotion of harmonious social relations by allowing family and friends to spend time together. Sunday, according to these courts, is a reasonable choice.

I am of the opinion that such a position disguises the culturally-ladened content of the dominant norm. In spite of claims that the legislation is secular in nature and purpose, it is well-known that Sundays, Christmas Day, New Year's Day and Easter were chosen as business holidays in accordance with the Christian calendar. Indeed, Dickson C.J. in Edwards does not deny this. He states that Christian holidays merely reflect the heritage of the majority and that their history cannot be repudiated by the courts. ${ }^{32}$ Nonetheless, I believe that the former Chief Justice's argument in R. v. Big M Drug Mart Ltd., ${ }^{33}$ which dealt with an obviously non-secular law, is still relevant when examining a law that seemingly lacks theological content but which may promote a feeling of exclusion among non-believers:

In proclaiming the standards of the Christian faith, [the Lord's Day Act] creates a climate hostile to, and gives the appearance of discrimination against, non-Christian Canadians. It takes religious values rooted in Christian morality and, using the force of the state, translates them into a positive law binding on

(1986| 2 S.C.R. 713

31. (199I), 2 O.R. (3d) 65 (Ont. C.A.).

12. Supra, note 30 at $742-44$.

3. [1985] I S.C.R. 295. 
believers and non-believers alike. The theological content of the legislation remains as a subtle and constant reminder to religious minorities within the country of their differences with and alienation from. the dominant religious culture. ${ }^{34}$

Consequently, although the importance of a common pause day is stressed by the judiciary, ${ }^{35}$ it places those who choose not to discontinue their commercial activities at a disadvantage. The dominant Christian norm is hidden in the ostensibly secular notion of "common pause," and the differences of other cultures are ignored.

As a postscript to this example, some may think it ludicrous that we have to even consider modifying common practices such as the calendar to accommodate differences and multiculturalism. It should be noted, however, that the importance of a common pause day may be diminished by the fact that legislation such as the one discussed above is limited only to the activities of retailers and their employees (as well as to some extent, the conduct of consumers); numerous groups such as factory workers and professionals frequently have to work on Sundays. Secondly, our common understanding of the calendar and work may be changing. Witness the demands being made by certain groups of blue-collar workers for a four-day work week. Given these considerations, it may not seem important enough to sacrifice our notion of cultural equality and the eradication of a dominant norm in the name of a so-called common pause day. The lesson to be taken from such an example is that we must not automatically rule out the possibility of changing common practice. In the end, it may be easier, and possibly more necessary, to do so than we currently believe.

Thus, the existence of the dominant norm hidden in a camouflage of universality and neutrality results in stigmatizing minority groups. Contending with this difficult problem involves the "dilemma of difference": ${ }^{36}$

\footnotetext{
Identification or acknowledgement of a trait of difference, associated by the dominant group with minority identity, risks creating occasions for majority discrimination based on that trait. Nonidentification or nonacknowledgement, however, risks recreating occasions for discrimination based on majority pracrices, such as tests, norms, and judgments forged without regard for difference, or with regard solely for the perspective, needs, and interests of the dominant group. ${ }^{37}$
}

When everything is relative to this "universal norm," difference is described through a terminology of disadvantage in comparison to a superior standard of humanity or in terms of what attributes are absent in the minority group: ${ }^{38}$

34. Ihid. at 337 [emphasis added].

35. This was done particularly by Dubin C.J. in Peel v. A\&P, supra, note 31 at 87-90.

36. M. Minow, "Learning to Live with the Dilemma of Difference: Bilingual and Special Education" (1985) 48 Law and Contemporary Problems 157.

37. Ibid. at 160 [emphasis added].

3x. K.W. Crenshaw, "Race, Reform, and Retrenchment: Transformation and Legitimization in AntiDiscrimination Law" (1988) 101 Harvard L.R. 1331 at 1380; Young, supra, note 28 at 170. 
The terminology of disadvantage may actually reinforce the values and standards of dominant groups in society, if the group differences from which disadvantage flows are labelled undesirable rather than recognizing the social construction that renders these differences problematic. ${ }^{39}$

The solution, I believe, is to assert the value and specificity of culture through multiculturalism. This will force the relativization of the dominant culture and, in turn, make it more difficult for the practices of the dominant culture to be seen as the universal norm. ${ }^{40}$ It may involve a mere emphasis of cultural difference to point out that some practices are not always done in the manner that they are commonly thought to be done in. Further, such an assertion could require more radical measures, such as changing ageold institutions, as were observed previously in relation to Sunday-closing legislation.

Equality and mutual understanding among cultures are facilitated in the absence of "common" standards which, in reality, are frequently majority practices. If everyone recognizes that there are different ways of doing things and that there are no generallyaccepted or superior standards with which to compare these differences with, then Group A will not have any moral grounds for thinking that it should be able to impose its standards on Group B. Thus, Group A may realize that Group B is "not like us." However, Group A will also understand that as members of Group A, "we are not like them." Realizing that they are a group among other groups may diminish the animosity which frequently occurs when feelings of cultural arrogance arise. In order to accomplish this understanding, we must constantly question the norm, devise new approaches to differences and see them in a "non-hierarchical, non-pejorative way. ${ }^{41}$ This is because groups will not be seen as equal in society until "their specific experience, culture, and social contributions are publicly affirmed and recognized." 42

As a result, a more effective policy of multiculturalism will allow for accommodation and will emphasize differences of all cultural groups. It is through this policy that equality can be better achieved.

In the Canadian context, however, our multicultural policy has not succeeded due to the constraining effect of our historical and legal commitment to duality. The ability to emphasize difference is severely hampered because of our eternal preoccupation with the cultural/linguistic dichotomy of French and English. I will attempt to explain Canada's experience with multiculturalism in the following section.

39. Sheppard, supra, note 21 at 222.

*). Young, supra, note 28 at 166.

41. L.M. Finley, "Transcending Equality Theory: A Way Out of the Maternity and Workplace Debate" (1986) 86 Columbia L.R. 1118 at II52-53; Crenshaw, supra, note 38 at 1380-81. 


\section{THE HISTORY OF MULTICULTURALISM IN CANADA}

Before analyzing the status of multiculturalism today, the historical premises of duality and pluralism in Canada must be examined. This is important so as to understand how these two concepts originated and how they became engraved on the Canadian political, legislative, and constitutional agenda.

\section{A. CONFEDERATION}

Through Confederation, the problem of the unstable relationship between the French and English was considered to be solved. ${ }^{43}$ Indeed, the Constitution Act, $1867^{44}$ was founded upon the principle of dualism. Provisions such as ss. 133 and 93, and 92(13) in the new Constitution, provided a vehicle of necessary autonomy for the two dominant populations, particularly for the French in Quebec, so as to protect their respective cultures. ${ }^{46}$ Note also that s. 91(24) transformed native peoples into Canada's first "ethnic" minorities. ${ }^{47}$ In sum, the creation of the federal system in 1867 was the direct result of the requirements of a binational state ${ }^{48}$ and established an infrastructure that, in the near future, would necessarily require accommodation for multiculturalism.

\section{B. THE 1960s: THE ROYAL COMMISSION ON BICULTURALISM AND BILINGUALISM}

During the first decades of the twentieth century, it did not appear likely that there would be cultural accommodation of any type in Canada. To some extent, turn-of-thecentury Canada was obsessed with an attempt to enforce homogeneity according to British standards. ${ }^{49}$ However, the government soon realized that such a policy did not work and that the notion of cultural diversity might in fact be easier to reconcile with national

43. Duclos, supra, note 3 at 341 .

4. (U.K.), 30 \& 31 Vict., c.3.

45. S. 133 provides for the use of English and French in Parliament, and the various legislatures; s. 93 allows the province to legislate with regards to education, particularly denominational schools. It was understood at the time that Roman Catholic meant French schools and that Protestant implied English due to the statistical reality of the population: s. 92(13) gave the province authority to legislate in the matters of property and civil rights, thus, allowing Quebec to regulate a great deal of its intermal affairs without interference from Ottawa.

th. Duclos, supra, note 3 at 341; see also F.R. Scott "Arcas of Conflict in the Field of Public Law and Policy" in M. Wade, ed.. Canadian Dualism: Studies of French-English Relations (Toronto: University of Toronto Press, 1960) 81.

47. Kallen, supra, note 9 at 354, where the author stales that native peoples were made "wards of the state."

48. Magnet, supra, note 15 at 768.

49. M.R. Hudson, "Multiculturalism, Government Policy and Constitutional Enshrinement - A Comparative Study" in Canadian Human Rights Foundation, ed., Multiculturalism and the Charter: A Legal Perspective (Toronto: Carswell, 1987) 59 at 60. 
unity ${ }^{50}$ The $1960 \mathrm{~s}$ resulted in the culmination of this train of thought through the investigation undertaken by the Royal Commission on Bilingualism and Biculturalism. ${ }^{51}$

Although, as the title of the Commission suggests, the initial focus was placed on the relationship between the "two founding races," Commission members were soon made to realize that the country's social composition was much more than two "races." Indeed, the terms of reference reflected this change of heart:

...to recommend what steps should be taken to develop a Canadian Confederation on the basis of an equal partnership between the two founding races, taking into account the contribution made by the other ethnic groups to the cultural enrichment of Canada and the measures that should be taken to safeguand that contribution. ${ }^{52}$

The Report's conclusions contain three points that should be noted for the purposes of this argument. First, general focus was placed on the elimination of discriminatory barriers in the name of equality as well as a recommendation that the Canadian government promote non-British, non-French cultures in Canada. ${ }^{53}$

Second, the Commission refused to consider Canada's diversity in terms of "ethnicity" seeing that vocabulary as being pejorative. The Commission was also of the opinion that "ethnic" difference as a principle for shaping society would create closed-membership groups based on accidents of birth which would result in the condemnation of newcomers as outsiders. ${ }^{54}$ Rather, the Commission suggested that Canadians understand the "other ethnic groups" (i.e. other than French or English) as "cultural groups" - defined as "a way of being, thinking and feeling" through a common tongue, similar customs, habits and experiences. ${ }^{55}$

Third, although representation by Canada's "other ethnic groups" forced the Commission to realize that it had a "Third Force" ${ }^{66}$ to contend with, the Report nonetheless concluded that those groups were not sufficiently concentrated or cohesive enough to warrant an expansion of the two-society principle. However, it was noted that if, at any time in the future, there arose an occasion where a sufficient number of

50. Ibid. at 61 .

51. Infra, notes 52 and 53.

52. Canada, Report of the Royal Commission on Bilingualism and Biculturalism, The Official Languages, Book I (Ottawa: Queen's Printer, 1969) at xxi.

53. Canada, Report of the Royal Commission on Bilingualism and Biculturalism, The Cultural Contribution of the Other Ethnic Groups, Book IV (Ottawa: Queen's Printer, 1969) at 5; Hudson, supra, note 47 at 63.

34. Canada, Report of the Royal Commission on Bilingualism and Biculturalism, Book I, supra, note 52 at Xxiii.

55. Canada, Report of the Royal Commission on Bilingualism and Biculturalism, Book IV, supra, note 53 at 11.

5t. This was the term coined by Senator Paul Yuzyk in a speech to the Senate in 1963, Hudson, supra, nole 49 at 63. 
Canadians ordinarily used and wished to continue to use a language other than English or French, recognition of the language could be confirmed by law or regulation. ${ }^{57}$

\section{THE 1970s: MULTICULTURALISM WITHIN A BILINGUAL FRAMEWORK}

The multiculturalism policy introduced in the 1970s adopted the Commission's Report and provided the now famous characterization of "a policy of multiculturalism within a bilingual framework." It was recommended that: (a) resources be given to cultural groups to assist them in growing and in contributing to Canada; (b) members of all cultural groups be assisted in overcoming cultural barriers to full participation in Canadian society; (c) promotion of interaction among all cultural groups take place in the interest of national unity; and (d) continued assistance should be given to immigrants in order for them to learn at least one official language so that they can become full participants in Canadian society. ${ }^{58}$ Essentially then, the policy presented a combination of assimilation and preservation of cultural distinctiveness.

The aims of the drafters of the policy during this time were noble:

...[we] rejec[t] the theory that Canada is divided into only two cultures, not because we do not wish to give full protection to the rights of the French-speaking citizens, but because the concept is too confined to do justice to our reality as a people. In the sociological sense most would agree that there is a Frenchspeaking Canadian nation, but there is no single English-speaking nation in the same sense. In the face of this cultural plurality, there can be no official Canadian culture or cultures. ${ }^{59}$

The traces of "biculturalism" emphasized during the 1960s were now replaced by the concept of an absence of any one official culture. Nevertheless, certain groups objected to this policy feeling that it reduced them to "cartoon images of culture."60

One may wonder whether such a structure - multiculturalism within a bilingual framework - accompanied by the disavowal of a single official culture - is conceptually feasible. From preliminary observations, such an arrangement would seem to deny the almost-inevitable link between language and culture: in other words, is it possible to have an official language policy without an official culture? If the policy is able to keep the two distinct from each other, then an equality of cultures leading to a successful policy

57. Canada, Report of the Royal Commission of Bilingualism and Biculturalism, Book IV, supra, note 53 at 13.

58. Hudson, supra, note 49 at 63 citing the House of Commons debates which occurred on October 8 , 1971.

59. Special Joint Committee of the Senate and the House of Commons on the Constitution of Canada, Final Report, Fourth Session, 28th Parliament, 1972 at 2 (Joint Chair: G.L. Molgat \& M. MacGuigan) [emphasis added]. 
of multiculturalism is possible. These considerations should be kept in mind as we continue with this historical assessment.

\section{THE 1980s: CONSTITUTIONALIZATION AND LEGISLATION}

The 1980s saw a re-affirmation of both bilingualism and multiculturalism in the form of the constitutionalization of the two principles. The Canadian Charter of Rights and Freedoms provides strong protection of the notion of official languages. Seven provisions $^{61}$ entrench official bilingualism while only one section deals with multiculturalism. Section 27 reads:

This Charter shall be interpreted in a manner consistent with the preservation and enhancement of the multicultural heritage of Canadians.

As one commentator observes, dualism was confirmed and bolstered by the Charter through the provisions of positive, specified rights. However, no parallel protection was accorded to minority groups; indeed section 27 does not confer positive rights but, rather, is an interpretative clause. ${ }^{62}$

In any event, the notion of a viable multiculturalism policy co-existing with an official languages one began to find a comfortable niche in the psyche of Canadian policy. In response to a question by an international human rights committee regarding the situation of the various cultural groups and minorities living in Canada, the federal government replied that even though French and English are the official languages of Canada, "the rights and privileges acquired or possessed by virtue of law or custom" of any other cultures have not changed. ${ }^{63}$

This line is echoed in the 1988 Canadian Multiculturalism Act, where the preamble declares:

And whereas the Constitution of Canada and the Official Languages Act provide that English and French are the official languages of Canada and neither abrogates or derogates from any rights or privileges acquired or enjoyed with respect to any other language.

S. 16 declares French and English as the official languages of Canada; ss. 17-19 provide for the use of both languages in Parliamentary functions; s. 20 requires the provision of federal government services in both languages; ss. 21-22 are non-abrogation/derogation clauses; s. 23 provides for minority education language rights. (Note as well, that to some extent, s. 29, the denominational schools protection clause, is considered to be part of this group).

62. Kallen, supra, note 9 at 356-57.

63. Department of the Secretary of State, Supplementary Report of Canada on the Application of the Provisions of the International Covenant on Civil and Political Rights in Response to Questions Posed by the Human Rights Committee in March 1980 (March 1983). 
This essentially declaratory piece of legislation proclaims that equal treatment and protection under the law should be provided while still "respecting and valuing...diversity." ${ }^{\text {"th }}$ Additionally, the promotion of multiculturalism and the use of non-official languages are emphasized in the Act; however, the caveat of French and English is always present. ${ }^{65}$

There is a strong relationship between the Multiculturalism Act and the Official Languages Act. ${ }^{66}$ In fact, the preamble of the latter could easily be substituted for that of the former. ${ }^{67}$ The Official Languages Act also pays tribute to multiculturalism within a bilingual framework. Proof of this can be seen through references to English and French-speaking Canadians "without regard to their ethnic origin" that permeate the legislation.

Thus, at the end of the 1980s, it was commonly held that the government's commitment to multiculturalism and bilingualism dovetailed handily in the uniquely Canadian context. Even the failed Meech Lake Accord ${ }^{68}$ did not neglect to provide for multiculturalism. While s. 2 of the Accord recognized the existence of English and French-speaking Canadians as a fundamental characteristic of the country, s. 16 countered by stating that nothing in s. 2 would affect the multiculturalism provision of s. 27 or other sections of the Charter and the Constitution Act, 1982.

I believe, however, that although the intentions of the constitutional framers are commendable, the constraints of official bilingualism are too narrow to allow for the pursuit of a full-fledged policy of multiculturalism which entails the equality of cultural groups. The next section will examine the actual impact of the government's direction over the last thirty years.

\section{S. 3(1)(e).}

Examples of the application of this Act include the Race Relations and Cross-Cultural Understanding program (elimination of discrimination through supporting community organizations and working with key institutions), the Heritage Cultures and Languages program (encourage and support cultural heritage through studies and education) and the Community Support and Participation program (assist groups to integrate first-generation Canadians, support ethnocultural/multicultural groups). More generally, the Minister of State for Multiculturalism and Citizenship promotes the "multicultural reality" of Canada, supports institutional change (to allow for full participation of all individuals), promotes the preservation, enhancing and sharing of heritage (festivals, conferences) and ensures the opportunity for employment in the civil service. See supra, note 4.

os. For example, see s. 3(1)(i), "...while strengthening the status and use of the official languages of Canada;" and s. 3(1)(j) where the federal government should "...advance multiculturalism throughout Canada in harmony with the national commitment to the official languages of Canada."

66. S.C. 1988, c.38.

67. An excerpt from the preamble of the Official Languages Act states:

And whereas the Government of Canada recognizes the importance of preserving and enhancing the use of languages other than English and French while strengthening the status and use of the official languages.... 


\section{THE REALITY OF CANADIAN MULTICULTURALISM}

\section{A. THE AMBIGUITY OF THE OFFICIAL DEFINITION OF MULTICULTURALISM}

Many authors attempt to make a distinction between culture and ethnicity. For example, it has been said that cultural pluralism can be the co-existence within a state of more than one culture (i.e. a historical community with a common language and history), or it can be polyethnicity (i.e. diversity through immigration) where immigrants are allowed to maintain some ethnic particularity but are also expected to integrate. Canada straddles both of these definitions ${ }^{69}$ and consequently confuses the two ideas. As a result, we are left with a situation where French-Canadians are afraid of being reduced to the status of immigrant groups and where immigrant groups are demanding equal status with the English and the French. ${ }^{70}$

What is this confusion, and what is its source? One suggested hypothesis is that the problem lies in the official position on multiculturalism which originated in the Royal Commission on Bilingualism and Biculturalism. As noted previously, the Commission refused to accept the term "ethnic" due to its seemingly pejorative nature. However, in replacing the term with "multicultural," it may have forgotten to modify its intentions as well. In other words, multiculturalism was intended to encourage, not cultures, but ethnic groups which are groups characterized by a sense of peoplehood. It is argued that although certain cultural traits are themselves part of ethnic identity, they do not constitute a complete, living and changing culture. The real intentions of the Commission, thus, may have been the promotion of polyethnicity and equality." I find it difficult to grasp the subtle differences between ethnicity and culture. It may, in fact, merely be a problem of semantics. Nevertheless, I do believe that, by not undertaking the difficult exercise of deriving a definitive meaning of "culture," equality, as the fundamental goal of multiculturalism, cannot be pursued. ${ }^{72}$ This is because we do not have a clear idea of what we are trying to preserve and promote. Perhaps then, all that we are left with is an understanding of multiculturalism which "turns out to be a choice of pizzas, wonton soup and kosher style pastrami sandwiches to which one can add ethnic radio programs." ${ }^{17}$ If this is the case, then multiculturalism, regardless of its definition, is a failure.

W. Kymlicka, "Liberalism and the Politicization of Ethnicity" (McGill Legal Theory Workshop, 21 September 1990) at 2 [unpublished].

lbid. at 3.

J. Bumet, "The Policy of Multiculturalism within a Bilingual Framework: An Interpretation" in A. Wolfgang, ed., Education of Immigrant Students, Issues and Answers (Toronto: Ontario Institute for Studies in Education, 1975) 205 at 208-09.

Magnet, supra, note 15 at 741 , referring to $\mathrm{H}$. Brotz.

Ibid. quoting $\mathrm{H}$. Brotz. 


\section{B. THE NEXUS OF LANGUAGE AND CULTURE}

\section{The Problem Stated}

In my mind, a second, more fundamental, problem is the relationship between language and culture. As the policy of the 1970s pronounced, and as legislation and constitutional changes of the 1980s affirmed, Canada has no official culture only official languages and a policy of multiculturalism.

This understanding must be seriously questioned. How viable is multiculturalism if it is tied to official bilingualism, a cultural policy from which language - a defining constituent - has been abstracted? Does it not essentially perpetuate the inequitable situation of the non-British, non-French inhabitants of Canada as not being part of the dominant culture $?^{74}$ On the other hand, how viable is the equal partnership between the English and the French that was so important to the Commission on Bilingualism and Biculturalism if bilingualism is deprived of its cultural significance? Does it destroy any basis for a Canadian nation and impede the development of a French-Canadian culture? ${ }^{75}$

These questions must be constantly considered. Given the intimate relation between language and culture, s. 27 of the Charter will have certain effects on the linguistic rights of non-French/English speaking minorities. ${ }^{76}$ However, s. 27 will go only so far as to not affect the privileged status of the two languages. In other words, the scope of s. 27 is limited by ss. 16 to 23 of the Charter. ${ }^{77}$ This is at odds with the position of the Supreme Court of Canada and its interpretation of the relationship between language and culture. In Mahe, language was considered "...more than a mere means of communication..." but, rather, "...part and parcel of the identity and culture of the people speaking it. ${ }^{78}$ In Quebec v. Ford ${ }^{79}$ language was qualified as a "...means by which a people may express its cultural identity. ${ }^{180}$ Consequently, if language is considered to be so essential to the content of a particular culture, then $\mathrm{s}$. 27 should not be limited by the official language clauses of the Charter. As we know, this is not the case.

74. Burnet, supra, note 71, referring to M. Lupul's "Multiculturalism with a Bilingual Framework: An Essay in Definition" at 208.

75. Ibid. at 207, referring to G. Rocher's argument in Le Quebec en mutation.

76. J. Woerlhing, "La constitution canadienne et la protection des minorités ethniques" (1986) 27 C. de D. 171 at 177 .

77. Ibid. at 180; D. Bottos, "Multiculturalism: Section 27's Application in Charter Cases Thus Far" (1988) Alta L. Rev. 621 at 631; D. Gibson, "Section 27 of the Charter: More than a Rhetorical Flourish" (1990) Alta L. Rev. 589 at 603, where he states:

Although s. 27 will materially assist Canada's multicultural garden to flourish, those hardy perennials, French and English, Protestantism and Catholicism, will continue to occupy the choiciest locations in the garden.

lbid. at 749. 
2. Does "Official Language" Mean "Official Culture"?: The "Working Reconciliation"

Another way of looking at the relationship between language and culture in the Canadian context is to ask whether we can necessarily preclude the existence of official cultures if there is a framework of official languages. Although the notion of official languages can be seen from a utilitarian point of view since it provides a common medium of communication allowing all groups to participate in society, it is also possible that an official language might represent a particular culture. ${ }^{81}$ In other words, does "English-speaking" signify "British," and is "French-speaking" tantamount to "Quebecois?"

Based on the latest census, given its greater diversity, there is no longer a British definition of English-speaking Canada ${ }^{82}$ which may have prevailed in the time of John Porter's writing of the classic The Vertical Mosaic in which he observed that

[c]ulture is a myth employed to restrict equality of opportunity for individuals, and multiculturalism a device for maintaining the British monopoly on clite positions in Canadian society. ${ }^{83}$

Although there has been increasing diversity in French-speaking Canada, it cannot be said that this linguistic group represents a multitude of origins. In fact, the policy-makers tend to assume that essentially French-speaking Canada is Quebec. ${ }^{84}$ Proof of this assertion can be found in the constitutional activity that has taken place in the last decade.

First, with respect to the Charter, balancing ss. 16-23 with s. 27 does not produce surprising conclusions:

Ethnic minorities will take the point hard, but the thesis of [the Charter] is that, with respect to the language of government jobs, government services, religious instruction, schools and culture, anglophone and francophone minorities stand in a preferred position. The reason is wholly political. It is an attempt to forge a working reconciliation between Quehec and the rest of Canada. ${ }^{85}$

st. Kymlicka, supra, note 69 at 6.

82. A. Cairns \& C. Williams, eds., "Constitutionalism, Citizenship and Society in Canada, An Overview" in Constitutionalism. Cirizenship and Society in Canada (Toronto: University of Toronto Press, 1985) 1 at 24: see also Canada Ethnocultural Council, "A Dream Deferred: Collective Equality for Canada's Ethnocultural Communitics" in Behiels, ed., supra, note 9, 335 at 337, discussing the MacDonald Commission of 1985 which observed that English-Canada was multicultural, not British, and that French-Canada was no longer composed solely of the descendants of 65000 "habitants;" Census of Canada, 1986: English-only as mother tongue was $62 \%$ of the population, French-only $25 \%, 12.8 \%$ other. Note also that $25 \%$ of Canadians were of origin other than British or French.

This may be a statistical reality as observed in P. Poirier, "Use of French down outside Quebec, study says" The Glohe and Mail (26 March 1991) A5, where it was observed that only $60 \%$ of the 946,000 francophones outside of Quebec speak French at home.

Cairns \& Williams, supra, note 82 at 175, quoting J.E. Magnet in "The Charter's Official Language Provisions: The Implications of Entrenched Bilingualism," [emphasis added]. 
Second, s. 2 of the Meech Lake Accord defined Quebec as a society and the rest of French Canada as a population. ${ }^{86}$ In this sense, Quebec was encouraged to promote both an official language and a particular culture. ${ }^{87}$ If such an interpretation is accurate, the policy-makers' adamancy that Canada has no official culture seems to ring hollow in the face of the application of such policy.

Has this "working reconciliation between Quebec and the rest of Canada" always been the driving force behind constitutional change? On the basis of the historical survey undertaken in this paper, particularly the Constitution Act, 1867, the Commission on Bilingualism and Biculturalism, and Meech Lake, it appears so. Multiculturalism has always been an afterthought in the minds of policy-makers. Persistent lobbying by cultural groups was required in the 1960s to put multiculturalism on the agenda after the Commission initially set out to investigate bilingualism and biculturalism. ${ }^{88}$ The first draft of the Charter contained no reference to multiculturalism until interest groups made it an issue. ${ }^{89}$ As well, it was only after the mobilization of the relevant groups that $\mathrm{s}$. 16 was included in the Meech Lake Accord. ${ }^{90}$ In fact, perhaps the greatest impact that the last ten years has had on multiculturalism is that cultural communities have become more aware of their political influence in Canada. Indeed, the refusal to accommodate their aspirations in s. 2 of the Meech Lake Accord left a sense of resentment which, in the future, "could pit ethnic minorities against official language minorities." ${ }^{.91}$ As one member of a minority group explained:

We cannot support a constitution that ignores the multicultural reality of Canada, one whose underlying rationale is the outdated and discredited concept of two founding nations. A country that gives greater rights to its citizens based on their belonging to ethnic groups that came to Canada sooner is not our vision of what Canada is or should be. We are all immigrants or descendants of immigrants. We must all be treated equally and fairly. ${ }^{42}$

S. 2. (1) The Constitution of Canada shall be interpreted in a manner consistent with

(a) the recognition that the existence of French-speaking Canadians. centered in Quebec but also present elsewhere in Canada, and English-speaking Canadians, concentrated outside Quebec but also present in Quebec, constitutes a fundamental characteristic of Canada; and

(b) the recognition that Quebec constintes within Canada a distinct society. [emphasis added].

R. Breton, "The Concepts of "Distinct Society" and Identity in the Meech Lake Accord" in K.E. Swinton \& C.J. Rogerson, eds., Competing Constitutional Visions: The Meech Lake Accord (Toronto: Carswell, 1988) 3 at 6.

A. Parel, "The Mecch Lake Accord and Multiculturalism" in R. Gibbins, ed.. Meech Lake and Canada: Perspectives from the West (Edmonton: Academic Printing and Publishing, 1988) 171 at 172.

Gibson, supra, note 77 at 591. The author also remarks at 592 that "without section 27, parts of the Constitution would have a strong monolithic or (more often) duolithic overtones." Parel, supra, note 88.

Ibid. at 176.

92. J. Wocrlhing, "A Critique of the Distinct Society Clause's Critics" in Behicls, ed., supra, note 9. 17। at 175, citing Thor Broda's brief to the Special Joint Committee of the Senate and the House of Commons on the 1987 Constitutional Accord. 


\section{THE FAILURE OF MULTICULTURALISM IN CANADA}

\section{A. THE HIERARCHY OF CULTURES: QUEBEC}

As we have seen, multiculturalism in Canada accommodates and emphasizes difference only to the extent in which it does not interfere with the official linguistic duality of the country. Further, as it has been argued, this official position does not only protect two languages but also results in promoting a particular culture such as FrenchCanadian/Quebec to official status. As a result, the theory of multiculturalism that was offered at the outset of this paper, whereby equality can only be achieved if the differences and diversity of all cultural groups are emphasized, is not possible in Canada. Indeed, there exists a hierarchy of groups.

The best example of this hierarchy can be found in Quebec. The Quebec Charter of Human Rights and Freedoms $s^{93}$ includes a provision dealing with the cultural interests of minorities. Section 43 reads:

Persons belonging to ethnic minoritics have a right to maintain and develop their own cultural interests with the other members of their group.

Implicitly, this provision recognizes those "ethnic" groups which are not part of the majority and provides a special right to these groups. This provision is quite distinct from the Charter's s. 27 which requires interpretation consistent with the multicultural heritage of all Canadians, as s. 43 sets "ethnic" minorities apart from the majority. In fact, judicial interpretation and the Quebec government have recognized that the anglophone minority in the province is not to be considered an "ethnic minority." therefore, that the notion of two "official" cultures exists in Quebec with special status accorded to the French-speaking majority and to the minority anglophones who remain predominately of British origin. ${ }^{95}$

9. Supra, note 14.

9. Hudson, supra, note 49 at 82; Campisi v. P.G. Quebec (1977), C.S. 1067, where the court justifies this bestowal of status upon anglophones through the historical, economic and cultural power of this group. Such status may in the end, be both beneficial and harmful to the anglophone minority. They are not labelled with the sometimes derogatory title of "minority." However, they may also be deprived of the protection that other minority groups are afforded by legislative provisions such as s. 43.

95. According to the 1981 census, the mother tongue of 706,115 people was English, while 487,385 of the population was of British origin (approx. 68\%) in S. McLeod Arnopoulos \& D. Clift The English Fact in Quebec (Kingston: McGill-Queen's University Press, 1984) at 230-31.

This observation is more flagrant when it is taken into account that $50 \%$ of immigrants to the province are allophones (i.e. people speaking neither English nor French) in A. Picard, "Quebec denies racism charge" The Globe and Mail (26 March 1991) A4. 
According to the theory of multiculturalism postulated in this argument, a policy of dominant cultures does exist and results in offering subservient, explicit, specific "protection" to the "other" groups in Quebec society. Within such a framework, it is difficult to emphasize the differences of all groups in order to achieve equality, since the two dominant groups are explicitly segregated, or perhaps even elevated, from the rest.

\section{B. REBUTTING THE ARGUMENT FOR MULTICULTURALISM WITHIN A BILINGUAL FRAMEWORK}

The common argument in favour of this framework, both for Quebec and for the rest of Canada, is that a nation needs commonality and mutual identification in order to unify. ${ }^{96}$ Consequently, the recognition that

[t]hose of French and British origin - who have the definite advantage of having colonized Canada share with all Canadians the rights and obligations arising from the fundamental duality of Canada... in the name of the democratic spirit. ${ }^{97}$

provides a common theory of unity, thus, providing for a harmonious nation. The following will reveal two fundamental problems with such an argument.

\section{The Hidden Dominant Norm}

This identification that we attempt to pass off as "mutual" bears a striking resemblance to the world of the dominant norm. It is a norm of homogeneity, official languages and hidden official cultures which places unassimilated people at a disadvantage in terms of their status in their own eyes and in the eyes of the dominant cultures. ${ }^{98}$ A striking example of this is the aboriginal peoples of Canada. Why should these peoples and their claims be made to fit into categories and concepts of a dominant culture "in some form of equivalence, in order to be acknowledged?"199 Indeed, it is argued by some that the law must be rethought in order to accommodate the reality of native difference. ${ }^{100}$

\section{Who are the "Founding Peoples?"}

Secondly, we must determine what type of "fundamental characteristic of Canada" we wish to promote. The current one depicts a common theory of unity involving two dominant cultures to the detriment of aboriginal peoples and other cultural groups. We

9.

This argument also appears frequently in American discussions on the subject of multiculturalism, see Young, supra, note 28 at 178.

97. Canada, Report of the Royal Commission on Bilingualism and Biculturalism, Book IV, supra, note 53 at 5.

98. This point is similar to arguments made by Young, supra, note 28 at 178, if her American-context observations are applied to Canadian society.

99. A-K/M.E. Turpel, supra, note 6 at 151-52.

100. Macklem, supra, note 6. 
insist on referring to the English and French as the "founding peoples" of Canada. The reason for this may be political in nature:

...the federal official languages policy, including the language provisions of the Charter of Rights and Freedoms, was an attempt to instill in francophones a sense of loyalty to Canada by stating that French Canadians were one of the country's founding peoples. But this proved frustrating for both Canadians and Quebeckers. ${ }^{\text {II }}$

Regardless of its justification, such a characterization helps contribute to the notion of a cultural/ethnic hierarchy whereby those who do not identify with either group are left feeling that their contribution to society is somehow less recognized and less important. Who is to say when our nation has stopped being "founded"? Take, for instance, the recent debate over whether Canadians of the Sikh faith should be allowed to wear turbans as part of the ceremonial dress of the Royal Canadian Mounted Police. Those who opposed such a change argued that we needed to maintain some traditions which represent the character of Canada lest we dismantle our identity. However, it is a fact that Canadians of the Sikh faith have been part of the population of this country for the last 100 years. ${ }^{102}$ If these Canadians cannot properly represent themselves through the ceremonial, non-functional dress of a tradition which is "typically Canadian," who can?

Canada is still a "pioneer" society. As one author observed in reference to Quebec:

[F]rom an historic point of view, it is clear that Westem ethnic groups (Anglophones and Francophones) are no more the true founders of the Quebec nation than people of native, Black or Jewish cultural origins, to name only the oldest examples...A nation is not created by a written legal declaration, hut by all people who contribure to its development. ${ }^{103}$

As a result, a proper policy of multiculturalism is essential to ensuring the equality of all those who contribute to Canada's development. Consequently, the premise of "founding peoples" which involves only a select number of groups must be eradicated. ${ }^{104}$ If this is not done, any attempt at unification through such a method will only foster resentment and hostility among those groups not included in that defined group of "peoples."105

\footnotetext{
101. M. Sarra-Bournet, "Why Qucbec will wait no longer" The Globe and Mail (18 February 1991) A17.

102. J.F. Krauter \& M. Davis, Minority Canadians: Ethnic Groups (Toronto: Methuen, 1978) at 86 where it is noted that the first people of Sikh faith landed in British Columbia in the 1890s.

603. R. Vachon. "Who is a Quebecois?" in R. Vachon \& J. Langlais, eds., Who is a Quebecois?, trans. F.E. Morgan (Ontawa: Tecumseh Press Limited, 1983) 76 at 84 [cmphasis added].

104. This conclusion was advocated by a majority of those who made representations to the Spicer Commission (Citizen's Forum on Canada's Future. Report to the People and Government of Canada (Ottawa: Supply and Services. 1991) at 72). The Commission heard comments such as, "We must aim to have everyone feel part of the whole" and "This is a multi-racial country and constitutional/cultural considerations must be expanded beyond the English-French, Canada-Quebec questions."

10S. Young, supra, note 28 at 179.
} 


\section{THE ROLE OF INTERNATIONAL LAW}

Domestic concerns and obligations aside, relevant international law as embodied in the International Covenant on Civil and Political Rights contains provisions relating to culture. ${ }^{116}$ Article 27 provides:

In those States in which ethnic, religious or linguistic minorities exist. persons belonging to such minorities shall not be denied the right, in community with the other members of their group, to enjoy their own culture, to profess and practice their own religion, or to use their own language.

Although art. 27 has a collective aspect ("in community with the other members of their group"), the intention of those who drafted the provision was to benefit individuals. It was not intended to protect subsequently-created immigrant minorities but, rather, only those groups who were already well-defined and long-established. In fact, its primary purpose was to prevent state interference and discrimination and thus allow for equality. ${ }^{107}$ However, with the landmark case of Lovelace v. Canada, ${ }^{108}$ new interpretation has been given to art. 27. It has been made to include an affirmative obligation on the part of the state ${ }^{109}$ to provide resources and not to hinder the efforts of the minority group in preserving and developing its language and culture. ${ }^{110}$

It is perhaps telling of the failure of multiculturalism in that in providing a privileged constitutional status to the two principal linguistic groups in the country, Canada has gone beyond international requirements. " However, constitutional provisions regarding other cultural and linguistic minorities are sparse and do not offer sufficient protection. ${ }^{112}$

Note that, technically, international obligations carry no regulatory weight within the domestic context of Canada unless the treaty is implemented by Parliament. However, Canada is also signatory to the Optional Protocol to Imternational Covenam on Civil and Political Rights which provides individuals with recourse to the Human Rights Committee (an international body). Additionally, the majority in Keegstra recognized Canada's international commitment to its cultural groups and applied it to the s. 27 interpretation of s. 1 of the Charter, supra, note 16 at 47-53; the Canadian Multiculturalism Act also recognizes its obligations under this Covenant in the preamble.

Magnet, supra, note 15 at 747-48.

[1983] Can. Hum. Rts. Y.B. 305 (U.N. Hum. Rts. Ciee.).

Magnet, supra, note 15 at 749 .

Woerlhing, supra, note 76 at 175; see also Minority Schools in Albania. [1935] P.C.I.J. Reports $(A B / 64)$ 17, which demanded that in order for minority groups to co-exist with the majority, (a) equality with the majority and (b) promotion of cultural diversity were required.

Woerlhing, supra, note 76 at $186-87$.

Ibid. 


\section{CONCLUSION}

\section{A. THE PRESENT SITUATION}

It is evident, therefore, that the political, legislative, and constitutional structure of Canada is incompatible with multiculturalism. A proper policy of multiculturalism would provide for accommodation and an emphasis of the difference and diversity that is present in all cultural groups, including those of the majority culture. Through such a policy, we could endeavour to achieve social equality. However, as stated earlier, a wholehearted pursuit of this interpretation of multiculturalism is problematic. A lack of funds and resources constitutes one obstacle. In addition, modifying institutions that find their origin in the dominant norm will be especially difficult.

For example, allocating special status to native peoples which may flagrantly conflict with individual rights, ${ }^{113}$ or discarding the notion of a common day of rest will find many opponents. Nevertheless, pursuing "true" multiculturalism at this time is impossible due to the overriding policy concern of bilingualism and the misconception that there is no official Canadian culture.

Consequently, the most conspicuous solutions are grim. We may have to abandon our official languages policy. It may be necessary to discontinue any pursuit of multiculturalism at the official/public level, since any effort that we are making today is merely a "song and dance affair." 114 This latter conclusion arises out of our policy of paying lip service to the notion of cultural equality which may seem so obvious that inevitably a sense of resentment could be fostered among minority groups. In fact, some political commentators, in remarking upon the current constitutional crisis in Canada, have suggested that we abandon both our commitment to multiculturalism and to official languages. ${ }^{115}$ Indeed, one has gone so far as to state:

As an heir to European civilization, we must reiterate our commitment to individual liberty, individual rights, equality of opportunity, freedom of expression... We are a nation of distinct communities, but a liberal nation of distinct communities. ${ }^{16}$

As may be observed from this quotation, such an interpretation contradicts the importance placed in this analysis on groups and the significance of difference in the pursuit of equality.

113. Such as a proposal that in order to protect Inuit and Dené culture, new residents to the North may only acquire voting rights after three years of residence in W. Kymlicka, "Cut the Holes to Fit the Pegs" The Globe and Mail (19 February 1991) A17. See also supra, note 6.

114. Breton, stupra, note 2 at 53.

I1s. "To Each our own" The Globe and Mail (30 March 1991) D5, where the author described the policies as the "two fault lines" of unity.

116. "We must be more than a system that works" The Globe and Mail (30 March 1991) D5. 
The sad reality is that multiculturalism is a much-maligned principle that was never given the proper opportunity to be exercised fully. This was due to the constraints imposed upon it by the duality of English and French. This is unfortunate, because cultural diversity is not only important for its achievement of equality, but it is also a national resource. It is more than "clothes, food, and festivals." It has the potential to create a society that could conceivably become more than the sum of its parts. Nonetheless, given our disoriented policy of the last thirty years, the following statement may be the most accurate description of the situation in Canada today:

\begin{abstract}
When a country like Canada enshrines pluralism through policies such as multiculturalism and bilingualism and the guaranteeing of individual rights, the outcome is coexistence - no more, no less. It's a good stan in building a society out of diverse peoples. But there's a danger. If there is no subsequent vision, no national goals, no explicit sense of coexisting for some purpose. pluralism becomes an uninspiring end in itself. Rather than coexistence being the foundation that enables a diverse nation to collectively pursue the best kind of existence possible, coexistence degenerates into national preoccupation. Pluralism ceases to have a cause. The result: mosaic madness. ${ }^{117}$
\end{abstract}

\title{
B. SUGGESTED APPROACHES
}

1. Australian Reform: Dealing with the Cultural Assumptions of the Law

The Australian Law Reform Commission has proposed ${ }^{118}$ that equality should be promoted by

...systematically examining the implicit cultural assumptions of the law' and the legal system to identify the manner in which they may unintentionally act to disadvantage certain groups....and [promoting] an environment that is tolerant and accepting of social and cultural diversity and respects and protects the associated rights of individuals. ${ }^{119}$

This is tempered by enumerating certain principles that should be accepted by all inhabitants including a premise of an overriding commitment to their country (Australia) and an acceptance of basic structures of society such as the Constitution and the rule of law, tolerance and equality, parliamentary democracy, freedom of speech and religion, a national language (English), and equality of the sexes. ${ }^{120}$ Through such a compromise, a country could reduce the culturally-laden aspects of its legal system that are frequently based on the dominant norm while simultaneously assuring some elements of commonality that all inhabitants of a liberal democracy could accept. Applied to Canada,

117. R.W. Bibby, Mosaic Madness: The Poverty and Potential of Life in Canada (Toronto: Stoddart, 1990) at 103-04.

118. Australia Law Reform Commission, Multiculturalism and the Law. Issues Paper No. 9 (Sydney: January 1990).

119. Ibid. at 1 [emphasis added].

120. Ibid. at 2. 
as long as the national language(s) do not connote national culture as well, this proposal, if entrenched in the Constitution, could go a long way in promoting equality.

\section{Official Languages, not Official Cultures}

Second, if we could somehow ensure that our official languages policy is just that official languages and not official cultures - we could possibly instill a sense of nonexclusion in the cultural groups who are currently not represented by the policy. However, there is still the dilemma of the inherent connection between language and culture. If we are to promote and preserve cultural groups, how far can we go in fostering the language of that group without offending the official languages policy?

This problem may not be as serious as it seems if Canadians can be convinced of the social and economic value of acquiring a proficiency in English and/or French. Given the dynamic nature of culture, perhaps a group's conception of what their culture is can be modified, as their experience in Canada grows, to include the use of one of the official languages without undermining their feeling of self-worth. Indeed, multiculturalism itself may be transitional in nature where second generation Canadians seek full integration into the society in which they were born. ${ }^{121}$ Nevertheless, in accordance with the theory of multiculturalism presented in this paper, this desire to seek full integration should be voluntary and not the result of a need to join in any "culturally superior" norm.

Additionally, with the global prevalence within numerous cultures of languages such as English and French, it may be reasonable to state that language is a significant component of culture, but it is not, however, necessarily determinative of any one culture. Using this interpretation, we could possibly justify labelling English and French as languages that do not represent any particular culture.

\section{Eliminate the Notion of "Founding Peoples"}

I would also suggest that any premise of "founding peoples," whether they be qualified as French, English or Aboriginal, be discarded. There is absolutely no need to establish such a hierarchy particularly when it is obvious in this period of constitutional soulsearching that the "founding" of Canada is not over.

\section{Multiple Multicultural Societies}

Unfortunately, within the confines of the present constitutional and political debate, none of the above solutions sufficiently address Quebec's concern regarding the preservation and promotion of its language and culture. This is because Quebec insists on associating language with culture. It is also because giving constitutional primacy or 
recognition to a particular culture, as I have argued, is antithetical to the achievement of social equality.

An interesting proposal made by Professor Armand de Mestral during his testimony to the Beaudoin-Edwards Committee may present a viable solution. ${ }^{122}$ He suggests that we declare that Canada consists of two multicultural societies - one francophone and one anglophone. Both societies would be acknowledged as equal by means of the two official languages. Through this approach, the "notion of multiculturalism comprising some third group" would be discarded. Professor de Mestral states that this would also give the "French heritage and culture full legitimacy across Canada." ${ }^{23}$ This paper has already acknowledged that English-Canada is multicultural. ${ }^{124}$ However, by recognizing that French-Canadian society is multicultural as well, words such as "French heritage and culture" would imply several cultures. Consequently, there would be no hierarchy of cultures.

As can be seen from these suggested approaches, imagination and compromise are required as we struggle with the incompatibility of multiculturalism and bilingualism. The relationship between culture and language as it relates to multiculturalism will probably never be fully recognized nor understood. Indeed, the potential scope of multiculturalism may prove to be too great for multiculturalism to fully recognize cultural difference. However, perhaps by eroding aspects of Canada which results in cultural inequality, such as the existence of the culturally-laden dominant norm in the legal system and the legal and constitutional emphasis of particular cultures, we may finally be able to give multiculturalism credibility and purpose.

\section{AFTERWORD}

To some extent, the current federal constitutional proposals seek to address some of the problems addressed in this paper. ${ }^{125}$ The so-called "Canada clause"126 that is proposed to be entrenched in s. 2 of the Constitution Act, 1867 suggests that the amendment reflects characteristics and values such as equality of the sexes, recognition of the aboriginal peoples of Canada, and parliamentary democracy. The term "fundamental characteristics" (i.e. English and French) as mentioned in s. 2 of Meech Lake is absent. Consequently, there is no possible inference of "founding peoples."

However, regarding cultures and groups, words such as "tolerance" and "fairness" are used and "the contribution to the building of a strong Canada of peoples from many

\section{1).}

123. Ihid. at 9 .

124. See note 82.

125. Shaping Canada's Future Together: Proposals (Hull: Minister of Supply and Services Canada. 1991).

126. Ibid. at 9-10. 
cultures and lands" is acknowledged, but there is no mention of diversity, although the part is entitled "Shared Citizenship and Diversity." Meanwhile, the government's obligation to preserve the two linguistic majorities and minorities is recognized.

In accordance with the argument in this paper, and the approaches suggested, I must stress again the importance of making a provision for Canadian cultural diversity. A provision similar to that proposed by the Australian Law Reform Commission ${ }^{127}$ might serve as a suitable model. Mention could also be made of Canada constituting a multicultural society or, possibly, two multicultural societies, French-speaking and English-speaking. A constitutional entrenchment of the eloquently-worded preamble to the Multiculturalism Act ${ }^{128}$ would also be a welcomed inclusion.

Additionally, the proposed entrenchment of s. 25.1 into the Charter contains essentially the same terminology as the "distinct society" provision of the Meech Lake Accord. However, subsection 2 defines the "distinct society" as including a "French-speaking majority," "a unique culture," and "a civil law tradition." In accordance with the propositions advanced in this paper, "a unique culture" should be elaborated upon to ensure that this does not mean one particular cultural group. As well, the provision would be greatly enhanced by the inclusion of a fourth aspect, "multicultural society."

\footnotetext{
127. Supra, note 118.
}

128. Supra, note 5. It may be recalled that the preamble to the Multiculturalism Act speaks of the recognition of the diversity with regards to race, national or ethnic origin, colour and religion as a fundamental characteristic of Canada. Compare this to the wording of one of the characteristics of the proposed s. 2 which mentions

... a commitment to faimess, openness and full participation in Canada's citizenship by all people without regard to race, colour, creed,...or cultural background. (emphasis added) This comparison emphasizes the distinction between equality as it relates to its blindness to personal and group characteristics, and equality as it relates to the emphasis of difference and cultural diversity. 